\title{
Liberação e atividade de moléculas indutoras de fitoalexinas em rubiáceas tropicais: influência da metilesterificação de pectinas ${ }^{1}$
}

\author{
CLAUDIA A. DA SILVA² e MARCIA R. BRAGA ${ }^{2,3}$
}

(recebido: 14 de maio de 2003; aceito: 4 de março de 2004)

\begin{abstract}
Release and activity of phytoalexin-inducing oligosaccharides in tropical Rubiaceae: influence of pectin methylesterification). Two woody Rubiaceae species from tropical forest, Alibertia myrcifolia and Rudgea jasminoides, showed differences in relation to their capacity of producing phytoalexins, when challenged with fungi, and in the composition of the pectins from their cell walls. These species were compared in relation to the production and activity of phytoalexin-eliciting oligosaccharides derived from their leaf cell walls. Cell wall hydrolysis with Driselase showed that eliciting oligosaccharides were released from both species, although they are more easily obtained from Rudgea jasminoides, which presents positive phytoalexin response. Incubation of the cell walls with endopolygalacturonase promoted the production of oligosaccharides from $R$. jasminoides but not from Alibertia myrcifolia, which shows no phytoalexin response. Sequential hydrolyses with pectin-methylesterase and endopolygalacturonase that caused cell wall breakdown and release of eliciting molecules from A. myrcifolia, indicated the presence of pectins with different degrees of methylesterification between the two species. Additionally, oligosaccharides with low degree of polymerization (DP) were shown to inhibit phytoalexin response induced by a fungal elicitor or oligosaccharides with higher DP. These results suggest that the distinctive behavior between the Rubiaceae species in relation to phytoalexin production might be due to differences in the production of eliciting oligosaccharides from their cell walls as a consequence of the differences in the degree of the methylesterification and distribution of methyl-esters groups of their pectins.
\end{abstract}

Key words - methylesterification, monoclonal antibodies, oligosaccharides, pectin, phytoalexin

RESUMO - (Liberação e atividade de moléculas indutoras de fitoalexinas em rubiáceas tropicais: influência da metilesterificação de pectinas). Duas espécies arbóreas tropicais de Rubiaceae, Alibertia myrcifolia e Rudgea jasminoides, diferem na composição de pectinas de suas paredes celulares e na capacidade de produzir fitoalexinas quando inoculadas com fungos. Essas espécies foram comparadas em relação ao mecanismo de liberação e atividade de oligossacarídeos de paredes celulares indutores da síntese de fitoalexinas. Paredes celulares das espécies hidrolisadas com Driselase, por diferentes períodos, mostraram que oligossacarídeos indutores podem ser liberados a partir de paredes de ambas espécies, embora sejam mais facilmente obtidos de $R$. jasminoides, espécie que apresenta capacidade de sintetizar fitoalexinas. A incubação das paredes celulares com endopoligalacturonase promoveu a liberação de oligossacarídeos de $R$. jasminoides, mas não de A. myrcifolia, espécie que não produz fitoalexinas. A hidrólise seqüencial com pectinametilesterase e endopoligalacturonase, que promoveu a quebra da parece celular e a liberação de moléculas eliciadoras a partir de A. myrcifolia, indicou a presença de pectinas com diferente grau de metilesterificação entre as espécies analisadas. Adicionalmente, oligossacarídeos com pequeno grau de polimerização mostraram atividade inibidora da síntese de fitoalexinas induzidas por um eliciador fúngico e por oligossacarídeos com maior grau de polimerização. Esses resultados sugerem que a diferença no comportamento das duas rubiáceas com relação à indução de fitoalexinas em soja possa estar relacionada ao mecanismo de liberação de oligossacarídeos, como conseqüência das diferenças no grau de metilesterificação e distribuição dos grupos metil-ésteres das pectinas.

Palavras-chave - anticorpos monoclonais, fitoalexinas, metilesterificação, oligossacarídeos, pectina

\section{Introdução}

Os polissacarídeos pécticos são os polímeros mais complexos e abundantes da parede celular primária de dicotiledôneas, sendo representados por moléculas

1. Parte da Dissertação de Mestrado de C.A. Silva, Universidade Estadual de Campinas, Instituto de Biologia, Departamento de Biologia Celular e Estrutural.

2. Instituto de Botânica, Seção de Fisiologia e Bioquímica de Plantas, Caixa Postal 4005, 01061-970 São Paulo, SP, Brasil.

3. Autor para correspondência: bragamr@canalvip.com.br ácidas e neutras (Willats et al. 2001). Os homogalacturonanos, ramnogalacturonano I (RG-I) e ramnogalacturonano II (RG-II) são moléculas ácidas, constituídas por uma cadeia de resíduos de ácido D-galacturônico unidos por ligações $\alpha 1,4$, intercalados ou não por resíduos de ramnose. Nos homogalacturonanos, os resíduos de ácido galacturônico podem estar substituídos por grupos metila no carbono 6, mostrando diferentes graus de metilesterificação (McCann et al. 1994). Em presença de $\mathrm{Ca}^{2+}$, as cadeias pécticas com baixo grau de metilesterificação se 
associam, formando um gel rígido e insolúvel. Esta forma é freqüentemente encontrada em paredes de células maduras, que cessaram seu crescimento (Willats et al. 2001). O grau de metilesterificação tem influência sobre as propriedades gelificantes das pectinas e também limita ou impede a ação de pectinases sobre esses polissacarídeos (Sakai et al. 1993).

Várias funções são atribuídas às pectinas, tais como determinação da porosidade da parede celular e controle do trânsito de macromoléculas, adesão celular, hidratação através da formação de géis, plasticidade e flexibilidade da parede durante o crescimento e participação em mecanismos de defesa da planta ao ataque de patógenos (Darvill et al. 1992, Côté \& Hahn 1994, McCann et al. 1994).

A penetração dos tecidos vegetais por patógenos e sua subseqüente colonização freqüentemente envolvem a degradação de polissacarídeos da parede celular, através da liberação de várias hidrolases, sendo as pectinases as primeiras polissacaridases a serem produzidas nos tecidos infectados (Fraissinet-Tachet \& Fevre 1996). A ação destas pectinases microbianas sobre a parede celular de plantas leva à despolimerização dos polissacarídeos pécticos, especialmente os homogalacturonanos, podendo, simultaneamente, gerar fragmentos indutores (oligogalacturonídeos) capazes de eliciar respostas de defesa na própria planta, como a síntese de fitoalexinas (Davis et al. 1984, Cervone et al. 1987, Darvill et al. 1992).

Oligogalacturonídeos são liberados naturalmente pela ação de endopoligalacturonases (Endo-PGs) e pectina-liases de microorganismos (Alghisi \& Favaron 1995, Cervone et al. 1989). In vitro, os oligogalacturonídeos podem ser obtidos por hidrólise ácida parcial da parede celular (Hahn et al. 1981) ou por tratamento com pectinases (Nothnagel et al. 1983). A ação gradual da Endo-PG sobre a cadeia do homogalacturonano leva a um progressivo encurtamento da mesma, sendo seu limite de digestão oligômeros com grau de polimerização (GP) de 2-4.

A atividade da Endo-PG é diretamente influenciada pelo grau de metilesterificação (GM) das pectinas, que varia em diferentes tecidos e com o estádio de diferenciação da célula (McNeil et al. 1984). A atividade da Endo-PG pode ser favorecida pela ação da pectinametilesterase (PME), pectinase que catalisa a conversão do ácido poligalacturônico metilado em ácido poligalacturônico, através da clivagem dos grupos metilésteres (Alghisi \& Favaron 1995). A retirada dos grupos metil-estéres pode favorecer a ação da Endo-PG sobre as cadeias de homogalacturonanos (Daas et al.1999).
Trabalhos recentes têm mostrado que o reconhecimento, a ancoragem e a clivagem de homogalacturonanos por ação de Endo-PGs só ocorrem quando uma estrutura molecular mínima está presente neste substrato. Mort \& Chen (1996) relataram que a Endo-PG de Erwinia carotovora requer 4 resíduos de ácido galacturônico adjacentes não metilesterificados dentro de uma região parcialmente esterificada para exercer sua atividade catalítica. Daas et al. (1999) também demonstraram que a Endo-PG de Kluyveromyces fragiles necessita de uma seqüência com 4 ou mais resíduos de ácido galacturônico não esterificado para agir. Entretanto, Daas et al. (2000) descreveram modos de ação e degradação diferentes para três pectinas com o mesmo grau de metilesterificação, mas que mostravam diferenças na distribuição dos grupos metila ao longo da cadeia de homogalacturonano. Estes resultados indicam que não somente o GM, mas a distribuição destes grupos metilésteres também é importante para a ação das Endo-PGs.

Vários trabalhos correlacionam a resistência de plantas a patógenos ao GM das pectinas. Heitefuss \& Pagel (1989) e McMillan et al. (1993), trabalhando com batatas resistentes e suscetíveis à E. carotovora, correlacionaram o GM com a resistência à bactéria. Le Cam et al. (1994) sugeriram que, além do GM, a distribuição dos grupos metil-ésteres estaria relacionada com a suscetibilidade de diversos cultivares de cenoura ao fungo Mycocentrospora acerina.

Estudos relacionados à síntese de fitoalexinas em duas rubiáceas nativas tropicais, que diferem quanto à capacidade de produzir esses metabólitos de defesa quando inoculadas com fungos, revelaram diferenças nas frações pécticas das paredes celulares de suas folhas (Braga et al. 1991, 1998). Teores de pectinas ácidas foram detectados mais abundantemente em Rudgea jasminoides, espécie que produz fitoalexinas. A avaliação da presença de oligogalacturonídeos indutores de fitoalexinas nas paredes celulares dessas plantas também apontou para presença de moléculas mais ativas em Rudgea jasminoides quando comparada a Alibertia myrcifolia, espécie que não sintetiza fitoalexinas em resposta à inoculação com fungos (Braga \& Dietrich 1998).

No presente trabalho são relatadas diferenças no GM das pectinas de paredes celulares de A. myrcifolia e $R$. jasminoides, que levam a diferenças na liberação e atividade de oligogalacturonídeos e que podem estar relacionadas às diferenças na resposta fitoalexínica observada entre as duas espécies analisadas. 


\section{Material e métodos}

Material - Folhas completamente expandidas e sem lesões de Alibertia myrcifolia (Spruce ex Schum.) Schum. e de Rudgea jasminoides (Cham.) Müll. Arg. foram coletadas na mata da Reserva Biológica do Parque Estadual das Fontes do Ipiranga, do Instituto de Botânica de São Paulo - SP.

Sementes de soja [Glycine max (L.) Merr.] dos cultivares IAC-8 e IAC-18 foram gentilmente cedidas pelo Instituto Agronômico de Campinas, Campinas - SP.

Culturas do fungo Mucor ramosissimus Samutsevitsch foram mantidas em meio de cultura Batata-Dextrose-Ágar (BDA) por aproximadamente 8 dias no escuro a $25^{\circ} \mathrm{C}$, sendo seus esporos extraídos e utilizados para a obtenção do eliciador utilizado no bioensaio dos cotilédones de soja.

Preparação de cortes para Microscopia de Luz e Microscopia Eletrônica de Transmissão (MET) - Porções de $2 \mathrm{~mm}^{2}$ foram retiradas do mesofilo de folhas recém coletadas e imediatamente fixadas, à temperatura ambiente, em glutaraldeído $1 \%$ + paraformaldeído 2,5\% em tampão cacodilato de sódio $50 \mathrm{mM} \mathrm{pH} \mathrm{7,0.} \mathrm{Na} \mathrm{seqüência,} \mathrm{as} \mathrm{amostras}$ foram lavadas em tampão cacodilato de sódio $50 \mathrm{mM}$ (3 vezes, 15 min), pós-fixadas no mesmo tampão contendo $1 \%$ de tetróxido de ósmio por 1 h e 30 min. As amostras foram então lavadas em tampão cacodilato de sódio (3 vezes, $30 \mathrm{~min}$ ), desidratadas em série etanólica $(30 \%, 50 \%, 70 \%, 85 \%, 95 \%$ e $100 \%$ ), e o material foi infiltrado com resina LRWhite: etanol (1:1, 2:1, $48 \mathrm{~h}$ cada), seguido de mais $48 \mathrm{~h}$ em resina pura. A polimerização foi efetuada em estufa a $60^{\circ} \mathrm{C}$, durante $48 \mathrm{~h}$. Foram efetuados cortes semifinos $(250 \mathrm{~nm})$ em micrótomo LKB Bromma 8800 e estes colocados sobre lâminas de vidro e cobertos com uma solução de azul de toluidina (AT) $0,025 \%$ em tampão McIlvaine $\mathrm{pH} 4,0$, por 15 min à temperatura ambiente. Na seqüência, os cortes foram lavados rapidamente em água destilada e secos ao ar (Vidal 1977). A lâmina foi, então, imersa em xilol por 10 min e montada em Entellan. Os cortes foram observados em microscópio óptico Zeiss, Jenamed 2.

Para MET, o material foi seccionado em ultramicrótomo, sendo os cortes finos $(<100 \mathrm{~nm})$ montados sobre telinhas de níquel, conforme descrito por Freshour et al. (1996).

Imunolocalização com anticorpos monoclonais - Cortes finos montados sobre telinhas de níquel foram hidratados por $5 \mathrm{~min}$ com tampão Tris-salino (TBS) 10 mM. Os sítios de ligações inespecíficas foram bloqueados pela incubação dos cortes com 3\% de albumina de soro bovino (BSA) em tampão TBS e incubados por $60 \mathrm{~min}$ com os anticorpos monoclonais JIM-5 e JIM-7, que reconhecem pectinas com menor e maior GM, respectivamente (Knox et al. 1990, Willats et al. 2000). Os anticorpos foram cedidos pelo Dr. Keith Roberts do John Innes Institute - Inglaterra. Em seguida, os cortes foram lavados em tampão TBS e incubados com o $2^{\circ}$ anticorpo antirato $\operatorname{IgG}$ (Sigma) conjugado com ouro coloidal $(10 \mathrm{~nm})$ por 60 min, e lavados com tampão TBS e água destilada. As telinhas foram contrastadas com acetato de uranila $1 \%$ e citrato de chumbo, visualizadas a 80 kV em Microscópio Zeiss EM 902A e fotografadas.

Extração de paredes celulares - As paredes celulares foram extraídas a partir de $25 \mathrm{~g}$ de folhas frescas de A. myrcifolia e $R$. jasminoides, segundo procedimento descrito por Braga et al. (1998). As folhas foram lavadas em água corrente e homogeneizadas (5 vezes) em tampão fosfato de sódio $100 \mathrm{mM}$ $\mathrm{pH} 7,0$, em liquidificador, por $5 \mathrm{~min}, \mathrm{a} 5^{\circ} \mathrm{C}$. O material resultante foi centrifugado $(16.000 \mathrm{~g}, 10 \mathrm{~min})$ em seguida, os sobrenadantes foram descartados. O precipitado foi ressuspenso em água destilada, filtrado a vácuo em filtro de fibra de vidro GF/A e o resíduo re-extraído mais quatro vezes com clorofórmio: metanol $(1: 1 \mathrm{v} / \mathrm{v})$, acetona e éter etílico. $\mathrm{O}$ resíduo final foi seco em estufa a $50{ }^{\circ} \mathrm{C}$, moído e as fibras separadas em peneira tipo Granutest (malha 20), sendo o pó resultante considerado como parede celular.

Determinação do grau de metilesterificação das pectinas Pectinas foram obtidas a partir das paredes celulares de A. myrcifolia e $R$. jasminoides por extração com oxalato de amônio $500 \mathrm{mM}, \mathrm{pH} 7,0, \mathrm{a} 80^{\circ} \mathrm{C}$, por $1 \mathrm{~h}$, conforme descrito por Braga et al. (1998). O grau de metilesterificação (GM) foi calculado após saponificação das pectinas com $\mathrm{NaOH}$ 1,5 M a temperatura ambiente e acidificação a frio com $\mathrm{H}_{2} \mathrm{SO}_{4}$, segundo a fórmula:

$\%$ de metilesterificação $=(\mu$ moles de metanol liberado $\times 100$ ). $\mu$ moles de ácido urônico ${ }^{-1}$

O conteúdo de metanol liberado foi determinado segundo Wood \& Siddiqui (1971) e o conteúdo de ácidos urônicos conforme Fry (1988).

Hidrólise com Driselase - As enzimas contidas na Driselase (Sigma) foram parcialmente purificadas, através da eliminação de açúcares, segundo procedimento descrito por Fry (1988). Vinte miligramas de paredes celulares foram incubadas a $25^{\circ} \mathrm{C}$ com $100 \mu \mathrm{L}$ de Driselase parcialmente purificada em $900 \mu \mathrm{L}$ de tampão acetato de sódio $20 \mathrm{mM}$, pH 4,7 por 1, 2, 4, 6 e $8 \mathrm{~h}$. Os controles foram efetuados pela substituição da enzima por $100 \mu \mathrm{L}$ de água destilada. A reação foi interrompida por fervura a $100^{\circ} \mathrm{C}$, por $5 \mathrm{~min}$. Os hidrolisados foram centrifugados a $7.800 \mathrm{~g}$ por $10 \mathrm{~min}$ e os sobrenadantes filtrados em filtro de fibra de vidro GF/A para a eliminação de resíduos sólidos. O volume dos sobrenadantes foi completado para $1,0 \mathrm{~mL}$ com água destilada e estes guardados a $-20^{\circ} \mathrm{C}$.

Hidrólise seqüencial com pectina-metilesterase (PME) e endopoligalacturonase (Endo-PG) - A vinte miligramas de paredes celulares de A. myrcifolia e $R$. jasminoides foram adicionados $500 \mu \mathrm{L}$ de tampão acetato de sódio $0,1 \mathrm{M}, \mathrm{pH} 4,4$ e $50 \mu \mathrm{L}$ da enzima pectina-metilesterase Sigma (PME). O controle foi efetuado pela substituição da enzima pelo volume equivalente em tampão. A incubação foi realizada por $1 \mathrm{~h}$, a $30{ }^{\circ} \mathrm{C}$. Os hidrolisados foram fervidos a $100{ }^{\circ} \mathrm{C}$ por $5 \mathrm{~min}$, centrifugados por 5 min e filtrados, sendo os sobrenadantes mantidos a $-20{ }^{\circ} \mathrm{C}$. Os precipitados de paredes resultantes deste tratamento foram lavados três vezes e ressuspensos em $250 \mu \mathrm{L}$ em tampão acetato de sódio 50 mM, pH 5,0. A essa 
suspensão foram adicionados $150 \mu \mathrm{L}$ de água destilada e $50 \mu \mathrm{L}$ da enzima endopoligalacturonase Megazyme (Endo-PG). Nos controles, a enzima foi substituída por $50 \mu \mathrm{L}$ de água destilada. Após $8 \mathrm{~h}$ de incubação a $30^{\circ} \mathrm{C}$, os hidrolisados foram novamente fervidos, centrifugados e os sobrenadantes resultantes foram filtrados, sendo seu volume ajustado para 1,0 $\mathrm{mL}$ com água destilada. Ensaios com tempo de incubação diminuído para 30, 60 e 90 minutos, e com apenas $10 \mu \mathrm{L}$ de Endo-PG foram efetuados. Incubações de paredes com Endo-PG, sem o tratamento prévio com PME, também foram realizadas.

Curvas de hidrólise das paredes celulares de A. myrcifolia e R. jasminoides foram efetuadas por $1 \mathrm{~h} \mathrm{com}$ PME $(50 \mu \mathrm{L})+$ Endo-PG $(10 \mu \mathrm{L})$ durante 1, 2, 4, 6 e 8 h. Os tratamentos de paredes celulares foram conduzidos variando-se o tempo de incubação com PME por 10, 20, 30 e 40 minutos, com tempo fixo de $4 \mathrm{~h}$ de incubação com a Endo-PG.

Ensaios colorimétricos - As quantidades de açúcares totais e de açúcares redutores presentes nos hidrolisados foram determinadas pelo método do fenol-sulfúrico (Dubois et al. 1956) e de Somogyi-Nelson (Somogyi 1945), respectivamente, tendo glucose $\left(100 \mu \mathrm{g} . \mathrm{mL}^{-1}\right)$ como padrão. O conteúdo de ácidos urônicos foi determinado utilizando-se o método de $m$-hidroxibifenil tendo ácido galacturônico $\left(100 \mu \mathrm{g}\right.$. $\left.\mathrm{mL}^{-1}\right)$ como padrão (Fry 1988, Filisetti-Cozzi \& Carpita 1991).

Análise dos hidrolisados por cromatografia líquida de alta resolução (HPAEC/PAD) - Os hidrolisados obtidos por ação da Driselase e de PME e Endo-PG foram analisados por HPAEC/PAD em sistema Dionex DX-300 e DX-500, para monossacarídeos e oligossacarídeos de ácidos urônicos (oligogalacturonídeos). Os monossacarídeos foram separados em coluna Carbo-Pac PA-1 em NaOH 20 mM isocrático por 30 minutos e identificados por comparação com padrões comerciais. Os oligogalacturonídeos foram analisados conforme descrito por Spiro et. al (1993), em coluna Carbo-Pac PA-1 no sistema DX-300 utilizando como eluente um gradiente linear de 400-800 mM de acetato de sódio, $\mathrm{pH}$ 8,0 , a um fluxo de $1 \mathrm{~mL} \cdot \mathrm{min}^{-1}$, durante $40 \mathrm{~min}$. Foi utilizada pós-coluna com $\mathrm{NaOH} 400 \mathrm{mM}$ a um fluxo de $0,5 \mathrm{~mL} \cdot \mathrm{min}^{-1}$. A coluna foi re-equilibrada com $400 \mathrm{mM}$ de acetato de sódio por 10 min antes da aplicação de uma nova amostra. Os tempos de eluição foram comparados com aqueles obtidos para padrões de oligogalacturonídeos de grau de polimerização 3-5 fornecidos pelo Dr. Stephen C. Fry (University of Edinburgh - Escócia). As análises no sistema Dionex DX-500 também foram efetuadas em coluna CarboPac PA-1, utilizando-se um gradiente linear de acetato de sódio de 400-800 mM em 100 mM de hidróxido de sódio, por 60 min. Os tempos de eluição foram comparados com aqueles obtidos para padrão de oligogalacturonídeos com grau de polimerização (GP) 7-22 fornecidos pelo Dr. Stephan Eberhard (University of Georgia - EUA).

Bioensaio de atividade indutora em cotilédones de soja Devido à variação sazonal na resposta fitoalexínica apresentada por rubiáceas nativas tropicais (Braga et al. 1991), a detecção da atividade indutora de fitoalexinas nos hidrolisados de paredes celulares foi efetuada em soja, segundo procedimento descrito por Ayers et al. (1976), com modificações. Os cotilédones de soja foram destacados de plântulas obtidas a partir de sementes germinadas e cultivadas em casa de vegetação, em bandejas plásticas, contendo vermiculita: terra vegetal (2:1), na forma de camadas, em temperatura ambiente e fotoperíodo controlado (14 horas luz.dia $^{-1}$ ), por aproximadamente 8-11 dias. Os cotilédones destacados foram desinfestados em solução de hipoclorito de sódio comercial a $10 \%$, durante 15 min e lavados exaustivamente em água destilada estéril. Discos de $6 \mathrm{~mm}$ de diâmetro e cerca de $1 \mathrm{~mm}$ de espessura foram retirados da superfície adaxial de cada cotilédone com o auxílio de um furador de rolhas e um bisturi. Gotas de $50 \mu \mathrm{L}$ dos hidrolisados resultantes dos tratamentos enzimáticos, de água destilada (controle) e do eliciador de esporos do Mucor ramosissimus (obtido segundo Cordeiro Neto \& Dietrich 1992) foram aplicadas sobre a superfície cortada de cada cotilédone. Grupos de 5 cotilédones foram colocados em placas de Petri, sob papel de filtro umedecido com água destilada, e estes incubados no escuro a $26^{\circ} \mathrm{C}$, por $20 \mathrm{~h}$. Todos os ensaios foram efetuados em triplicata. Após a incubação, os cotilédones foram lavados com água destilada $\left(1 \mathrm{~mL}\right.$. cotilédone $\left.\mathrm{e}^{-1}\right)$ e as soluções resultantes filtradas e avaliadas quanto à presença de fitoalexinas (gliceolinas) por leitura em espectrofotômetro a $286 \mathrm{~nm}$. A quantificação de gliceolinas foi efetuada utilizando-se padrão de gliceolina isolado de cotilédones de soja (Ayers et al. 1976).

Ensaios de competição entre oligossacarídeos indutores Hidrolisados provenientes da incubação de paredes celulares de A. myrcifolia e R. jasminoides com Endo-PG por 4 e $6 \mathrm{~h}$ foram diluídos 1:1 com água destilada ou com hidrolisados de paredes de $R$. jasminoides obtidos por tratamento com PME por $1 \mathrm{~h}$ e com Endo-PG por 4 ou $6 \mathrm{~h}$. Além disso, o eliciador do fungo M. ramosissimus foi também diluído a 3:1, 1:1 e 1:3 com água destilada e com os hidrolisados de paredes de A. myrcifolia provenientes do tratamento por $40 \mathrm{~min}$ com PME e $4 \mathrm{~h}$ com Endo-PG e de $R$. jasminoides tratadas por $1 \mathrm{~h}$ com PME e $4 \mathrm{~h}$ Endo-PG. Essas diluições foram ensaiadas em cotilédones de soja para avaliação da atividade indutora, conforme descrito acima. Os controles foram efetuados utilizando-se água destilada, os hidrolisados e o eliciador de M. ramosissimus a $100 \%$.

Análise estatística - As médias das determinações colorimétricas e de atividade indutora foram comparadas pelo teste estatístico de Tukey usando ANOVA.

\section{Resultados}

Driselase, uma mistura de 14 enzimas obtidas do fungo Irpex lacteus, capaz de hidrolisar a parede celular vegetal foi utilizada neste trabalho com o objetivo de 
simular alguns dos eventos que ocorrem durante a infecção de plantas por patógenos. A cinética de liberação de carboidratos a partir das paredes celulares das duas rubiáceas tratadas com Driselase foi bastante distinta, sendo que $R$. jasminoides liberou quase quatro vezes mais carboidratos que A. myrcifolia (figura 1A, B). A atividade indutora de fitoalexinas em cotilédones de soja também foi diferente para os hidrolisados das duas espécies analisadas, sendo bastante superior para $R$. jasminoides (figura $1 \mathrm{C}, \mathrm{D}$ ).

A análise da composição dos hidrolisados de paredes celulares tratadas com Driselase revelou a predominância de glucose e arabinose para A. myrcifolia, e de glucose, galactose e arabinose para
$R$. jasminoides (tabela 1). O aumento do tempo de incubação promoveu maior degradação da fração péctica, representada pelo aumento nos teores de ramnose, arabinose e galactose em A. myrcifolia e galactose em $R$. jasminoides. Para $R$. jasminoides, a hidrólise por $4 \mathrm{~h}$ também resultou na liberação de ramnose, indicando que neste caso o ramnogalacturonano I também passa a ser degradado, fato observado para A. myrcifolia com $8 \mathrm{~h}$ de hidrólise.

A determinação do grau de metilesterificação das pectinas das paredes celulares através de métodos colorimétricos mostrou que, em $R$. jasminoides, cerca de $30 \%$ de sua pectina encontra-se substituída por grupos metil-ésteres. Para A. myrcifolia, o valor encontrado
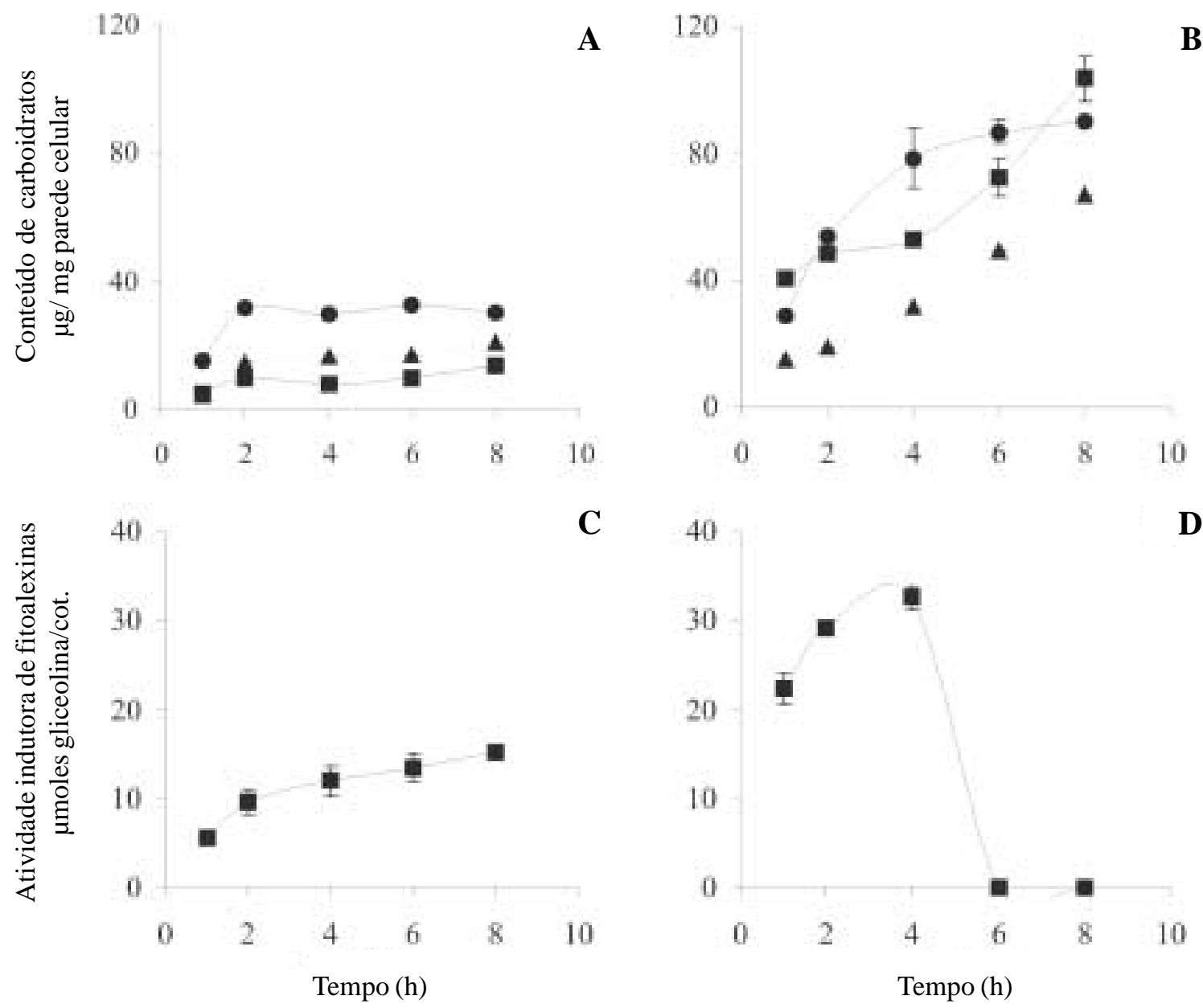

C

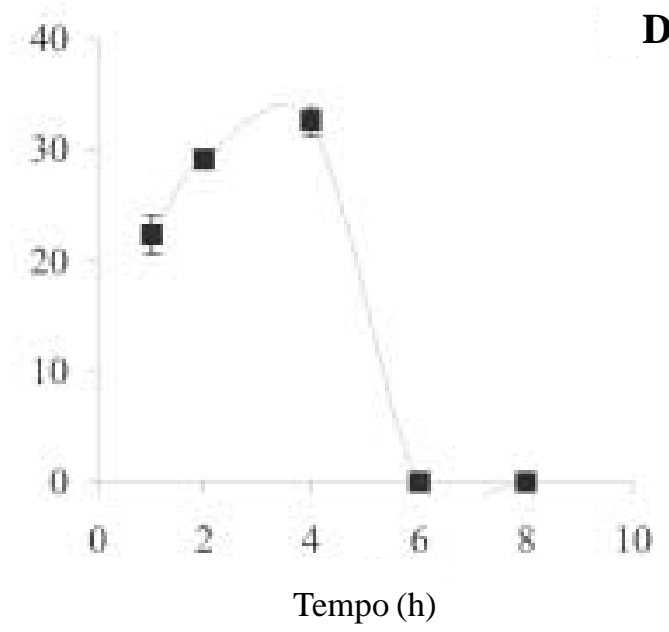

Figura 1. Conteúdo de carboidratos $(\mathrm{A}, \mathrm{B})$ e atividade indutora de fitoalexinas em cotilédones de soja $(\mathrm{C}, \mathrm{D})$ dos hidrolisados de paredes celulares de A. myrcifolia (A, C) e R. jasminoides (B, D) tratadas com Driselase por diferentes períodos. Em A e B: - = açúcar total; $\mathbf{\square}$ = ácidos urônicos; $\mathbf{\Delta}$ = açúcares redutores. As barras representam o desvio padrão da média.

Figure 1. Carbohydrate content (A, B) and phytoalexin-inducing actitivy in soybean cotyledons (C, D) of cell wall hydrolasates of $A$. myrcifolia $(\mathrm{A}, \mathrm{C})$ and $R$. jasminoides $(\mathrm{B}, \mathrm{D})$ after treatment with Driselase for different periods. In A and B: $\bullet=$ total sugar; $\mathbf{\square}=$ uronic acids; $\boldsymbol{\Delta}=$ reducing sugars. Bars represent average of triplicates \pm standard deviation. 
Tabela 1. Proporção relativa de monossacarídeos neutros presentes nos hidrolisados de paredes celulares de A. myrcifolia e $R$. jasminoides resultantes da incubação com Driselase por 4 e 8 h, obtida após análise por HPAEC/PAD. Rha = rhamnose, Ara $=$ arabinose, Fuc $=$ fucose, Xil $=$ xilose, $\mathrm{Gal}=$ galactose, Man $=$ manose e Glc $=$ glucose .

Table 1. Molar percentage of neutral monosaccharides in the cell wall hydrolysates of A. myrcifolia and R. jasminoides after incubation with Driselase for 4 and $8 \mathrm{~h}$, obtained by HPAEC $/$ PAD analysis. Rha $=$ rhamnose, Ara $=$ arabinose, Fuc $=$ fucose, $\mathrm{Xil}=$ xylose, $\mathrm{Gal}=$ galactose, Man $=$ mannose and Glc $=$ glucose .

\begin{tabular}{lccccccc}
\hline \multirow{2}{*}{ Espécie } & Tempo de hidrólise & \multicolumn{7}{c}{ Monossacarídeo (mol \%) } \\
\cline { 3 - 7 } & & Fuc & Rha & Ara & Gal & Glc & Xil/Man \\
\hline A. myrcifolia & $4 \mathrm{~h}$ & 0 & 0 & 14,3 & 6,1 & 76,3 & 3,4 \\
\multirow{2}{*}{ R. jasminoides } & $8 \mathrm{~h}$ & 0 & 1,1 & 18,7 & 9,2 & 68,5 & 2,5 \\
& $4 \mathrm{~h}$ & 0 & 3,3 & 9,4 & 11,5 & 72,3 & 3,5 \\
& $8 \mathrm{~h}$ & 0 & 1,9 & 7,1 & 14,6 & 74,6 & 1,8 \\
\hline
\end{tabular}

foi de $133 \%$, o que indica a existência de outros compostos metilesterificados, além dos ácidos urônicos.

A utilização de anticorpos monoclonais que reconhecem pectinas com diferentes graus de metilesterificação evidenciou, para $R$. jasminoides (figuras 2-6), a presença de maior quantidade de partículas de ouro coloidal na parede celular de células do mesofilo tratadas com o anticorpo JIM-5 (figuras 2, 4), em comparação à marcação com JIM-7 (figuras 3,6 ), confirmando que as pectinas presentes nas paredes celulares de $R$. jasminoides encontram-se pouco metilesterificadas. Diferenças na distribuição de pectinas foram observadas entre as paredes de células dos parênquimas paliçádico (figura 3) e lacunoso (figura 6). As paredes celulares de folhas de A. myrcifolia não foram marcadas pelos anticorpos (não mostrado).

Pela tabela 2, observa-se que paredes celulares de A. myrcifolia são pouco suscetíveis à hidrólise com Endo-PG quando comparadas às de $R$. jasminoides. O tratamento prévio da parede celular de A. myrcifolia com PME resultou em um aumento de cerca de 3 vezes no teor de ácidos urônicos liberados quando comparado à hidrólise somente com Endo-PG, indicando a presença de grupos metil-ésteres limitando a ação da Endo-PG.

Conforme mostrado pela figura $7, \mathrm{o}$ tratamento de $R$. jasminoides com Endo-PG resultou na liberação de oligogalacturonídeos de diferentes GP, incluindo aqueles de GP >12 e que sabidamente são moléculas com atividade indutora de fitoalexinas (figura 7D). Nenhum oligogalacturonídeo foi detectado para A. myrcifolia (figura 7C) no mesmo tipo de tratamento. Para esta espécie, apenas a incubação sequencial com PME e Endo-PG resultou na liberação de oligogalacturonídeos, porém em quantidades bastante inferiores àquelas detectadas para $R$. jasminoides (figura 7E).

Paredes celulares de A. myrcifolia hidrolisadas com Endo-PG por 1 a $8 \mathrm{~h}$ mostraram pequena liberação de ácidos urônicos, cerca de quatro vezes menor do que a observada para $R$. jasminoides (figura 8A, B). Para A. myrcifolia, o tratamento prévio com PME resultou em incremento na quantidade de ácidos urônicos (figura 8B). Para $R$. jasminoides, a incubação prévia com PME determinou menor liberação de ácidos urônicos a partir da parede celular dessa espécie, divergindo dos resultados mostrados na tabela 2 .

Não foi detectada atividade indutora de fitoalexinas em cotilédones de soja em nenhum dos hidrolisados de A. myrcifolia (figura $8 \mathrm{C}$ ), assim como naqueles de $R$. jasminoides tratados previamente com PME (figura 8D), estando a mesma presente somente nos incubados de $R$. jasminoides com Endo-PG até $6 \mathrm{~h}$ de incubação.

A análise de oligogalacturonídeos nos hidrolisados mostrou que o padrão observado não variou para cada espécie no decorrer do tempo de incubação. Para $R$. jasminoides, na incubação com Endo-PG e com $\mathrm{PME}+$ Endo-PG foram detectados oligogalacturonídeos com GP $\geq 7$ em todos os tempos de incubação. Para A. myrcifolia, oligogalacturonídeos de pequeno GP foram detectados a partir de $1 \mathrm{~h}$ de incubação com PME + Endo-PG, mas, mesmo assim, em menores quantidades que aqueles encontrados para $R$. jasminoides (dados não apresentados).

Paredes celulares de A. myrcifolia e $R$. jasminoides foram tratadas com PME por 10 a 40 min e com Endo-PG por $4 \mathrm{~h}$ (figura 9). Pode-se observar que a quantidade de ácidos urônicos liberada a partir de A. myrcifolia no tratamento com Endo-PG ainda é bastante inferior quando comparada a $R$. jasminoides e que o tratamento prévio com PME 


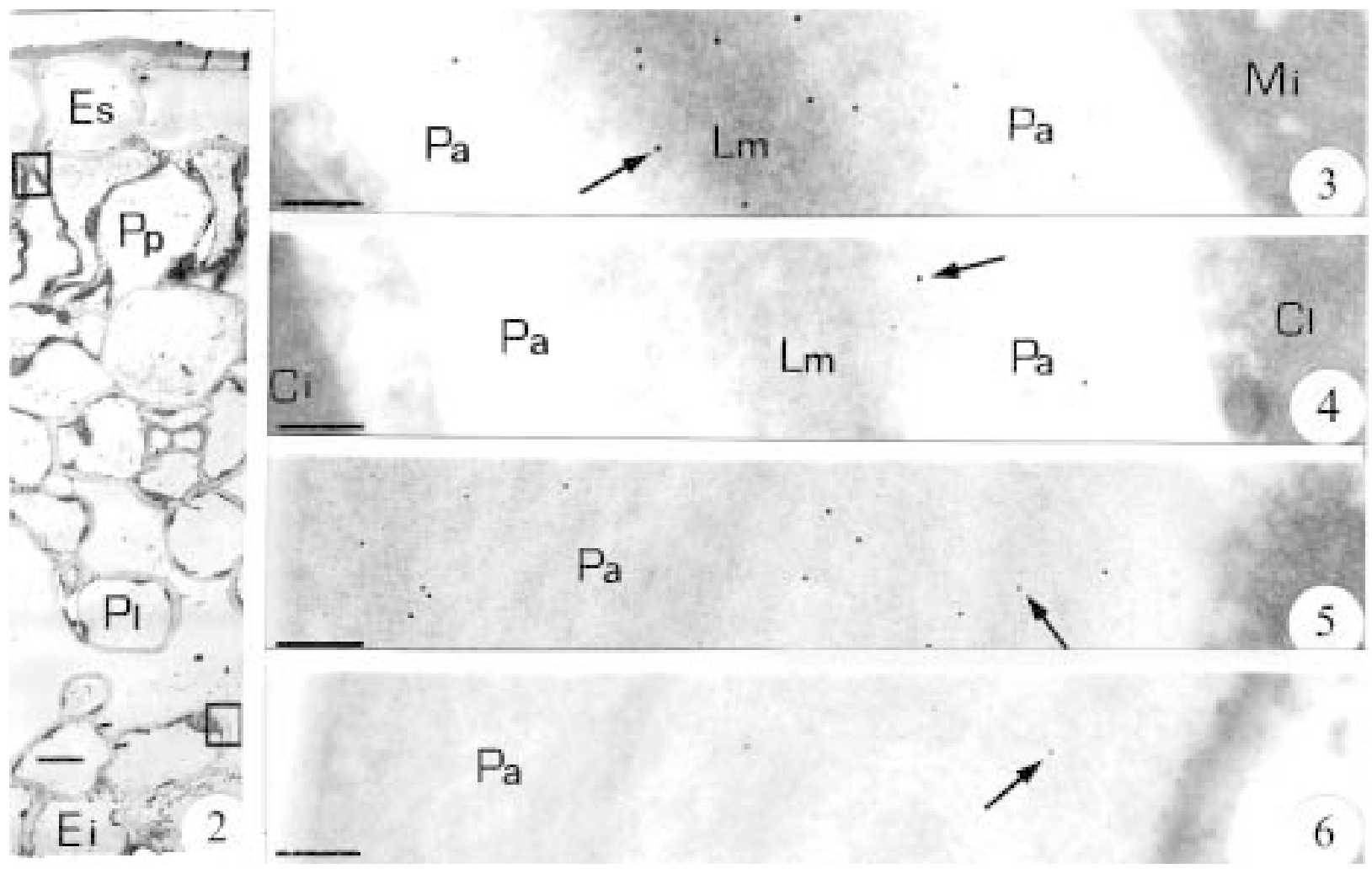

Figuras 2-6. Imunolocalização de pectinas de paredes celulares de folhas de $R$. jasminoides por Microscopia eletrônica de Transmissão (MET). 2. Corte transversal da folha, mostrando regiões de parede celular ampliadas nas figuras 4 a 6. 3-4. Paredes celulares do parênquima paliçádico imunolocalizadas, respectivamente, com os anticorpos monoclonais JIM-5 (pectina pouco metilesterificada) e JIM-7 (pectina bastante metilesterificada). 5-6. Parede celular do parênquima lacunoso imunolocalizada, respectivamente, com os anticorpos monoclonais JIM-5 e JIM-7. As setas indicam as partículas de ouro coloidal. Cl=cloroplasto; $\mathrm{Ei}=$ epiderme inferior; $\mathrm{Es}=$ epiderme superior; $\mathrm{Lm}=$ lamela média; $\mathrm{Mi}=$ mitocôndria $; \mathrm{Pa}=$ parede celular; $\mathrm{Pl}=$ parênquima lacunoso; $\mathrm{Pp}=$ parênquima paliçádico. Barras = $12 \mu \mathrm{m}(2), 0,14 \mu \mathrm{m}(3,4), 0,2 \mu \mathrm{m}(5,6)$.

Figures 2-6. Immunogold labelling of cell wall pectins in sections of leaves of $R$. jasminoides by Transmission Electron Microscopy (TEM). 2. Tranversal section of leaf with amplified region of the cell wall (squares) showed in 4 to 6. 3-4. Palisade cell walls immunolocalized, respectively, with monoclonal antibodies JIM-5 (low methylesterification) and JIM-7 (high methylesterification). 5-6. Spongy cell wall immunolocalized, respectively, with monoclonal antibodies JIM-5 and JIM-7. Arrows indicate gold particles. $\mathrm{Cl}=$ cloroplast; $\mathrm{Ei}=$ Lower epiderm; $\mathrm{Es}=$ Upper epiderm; $\mathrm{Lm}=$ middle lammela; $\mathrm{Mi}=$ mytocondria; $\mathrm{Pa}=$ cell wall; $\mathrm{Pl}=$ spongy; $\mathrm{Pp}=$ palisade. $\operatorname{Bars}=12 \mu \mathrm{m}(2), 0.14 \mu \mathrm{m}(3,4), 0.2 \mu \mathrm{m}(5,6)$.

promoveu um aumento nesta hidrólise, porém não mostrando variações significativas com o aumento do tempo de incubação (figura 9A). Para $R$. jasminoides, o tratamento prévio com PME ocasionou maior liberação de ácidos urônicos entre 10 e 20 min de incubação (figura 9B).

A aplicação dos hidrolisados sobre cotilédones de soja mostrou que, para A. myrcifolia, apesar da incubação prévia com PME ter ocasionado um aumento na quantidade de ácidos urônicos liberados, não foram produzidos oligogalacturonídeos ativos em soja em nenhum dos tratamentos. Para $R$. jasminoides (figura 9D), os hidrolisados provenientes do tratamento com Endo-PG apresentaram atividade indutora, como visto anteriormente (figura 9D). Os hidrolisados pré-tratados com PME mostraram atividade significativa entre $20 \mathrm{e}$ 30 minutos de incubação com PME. Entretanto, esta atividade ainda foi inferior à atividade do incubado somente com Endo-PG.

Oligogalacturonídeos com GP $\geq 9$ foram liberados em todos os tratamentos de paredes celulares de $R$. jasminoides, porém a quantidade e o GP não variaram significativamente nos tratamentos (figura 10A-C). Estes oligogalacturonídeos não foram observados para A. myrcifolia no mesmo tratamento (dados não apresentados). No hidrolisado previamente tratado com PME, para $R$. jasminoides, foram encontrados os mesmos oligogalacturonídeos vistos no 
Tabela 2. Conteúdo de ácidos urônicos liberados e porcentagem de hidrólise de paredes celulares de A. myrcifolia e R. jasminoides incubadas com PME por $1 \mathrm{~h}$ e Endo-PG por $8 \mathrm{~h}$.

Table 2. Uronic acid content in the hydrolysates and percentage of hydrolysis of cell walls of A. myrcifolia and R. jasminoides incubated with PME $1 \mathrm{~h}$ and Endo-PG $8 \mathrm{~h}$.

\begin{tabular}{lccccc}
\hline \multirow{2}{*}{ Tratamento } & \multicolumn{2}{c}{ A. myrcifolia } & & \multicolumn{2}{c}{ R. jasminoides } \\
\cline { 2 - 3 } \cline { 5 - 6 } & $\begin{array}{c}\text { mg ác. urônico/g } \\
\text { parede }\end{array}$ & $\begin{array}{c}\% \\
\text { hidrólise }\end{array}$ & & $\begin{array}{c}\text { mg ác. urônico/g } \\
\text { parede }\end{array}$ & $\begin{array}{c}\% \\
\text { hidrólise }\end{array}$ \\
\hline Parede + tampão acetato de sódio 50 mM & 0 & 0 & 0 & 0 \\
Parede + PME & 0,2 & 0 & 0 & 0 \\
Parede + Endo-PG & 2,2 & 0,2 & & 25,6 & 2,6 \\
Parede + PME + Endo-PG & 6,1 & 0,6 & 30,1 & 3,0 \\
\hline
\end{tabular}
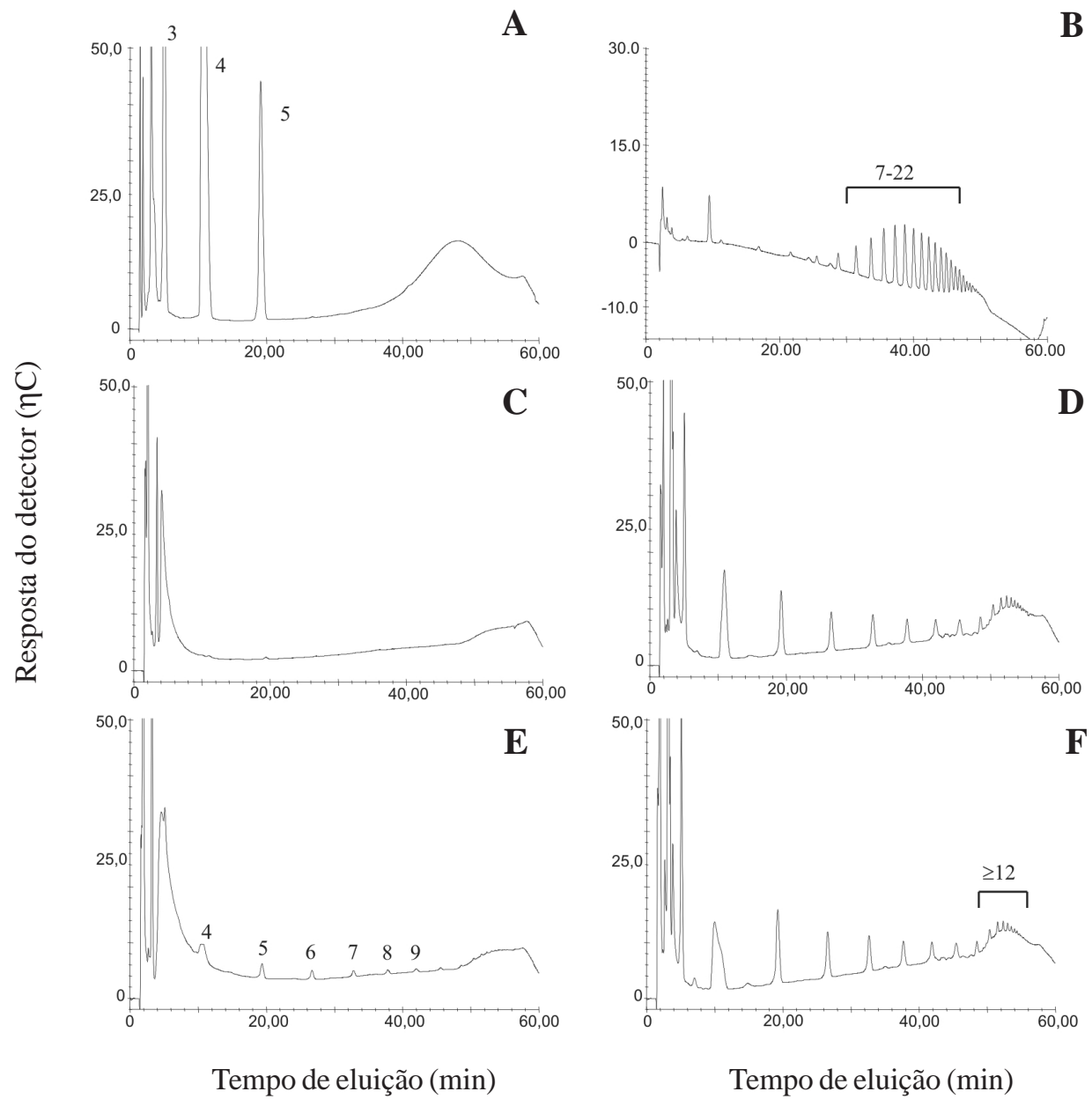

B
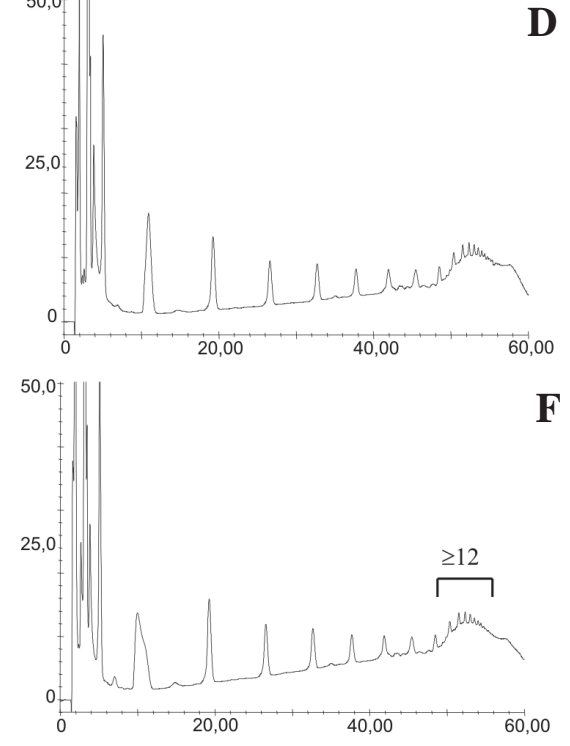

Tempo de eluição (min)

Figura 7. Perfil em HPAEC/PAD dos oligogalacturonídeos presentes nos incubados de paredes celulares de A. myrcifolia (C, E) e R. jasminoides (D,F) com Endo-PG (C, D) e PME + Endo-PG (E, F) por 90 min. Padrão de oligogalacturonídeos de GP 3-5 (A) e GP 7-22 (B). As incubações com 30 min não geraram oligogalacturonídeos em quantidades que pudessem ser detectadas por HPAEC/PAD e os perfis de eluição das incubações com de 60 min que foram similares ao tratamento com 90 min.

Figure 7. HPAEC/PAD profile of oligogalacturonides from cell walls of A. myrcifolia $(\mathrm{C}, \mathrm{E})$ and $R$. jasminoides $(\mathrm{D}, \mathrm{F})$ incubated with Endo-PG (C, D) and PME + Endo-PG (E, F) for 90 min. Oligogalacturonide standards of GP 3-5 (A) and GP 7-22 (B). Oligogalacturonides were not detected by HPAEC/PAD with $30 \mathrm{~min}$ incubation. Profiles of $60 \mathrm{~min}$ of incubation were similar to those of $90 \mathrm{~min}$. 

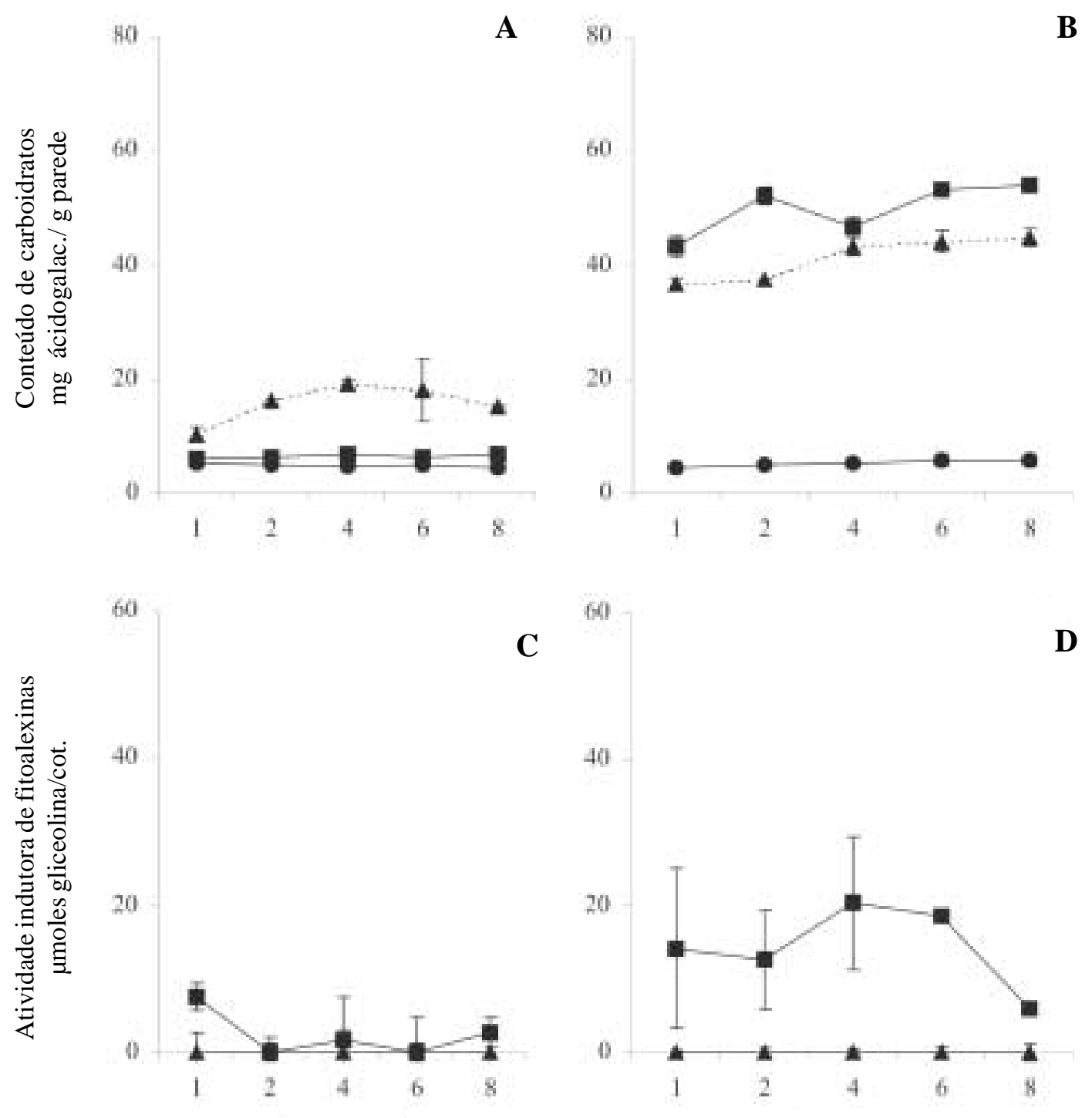

Tempo (h)

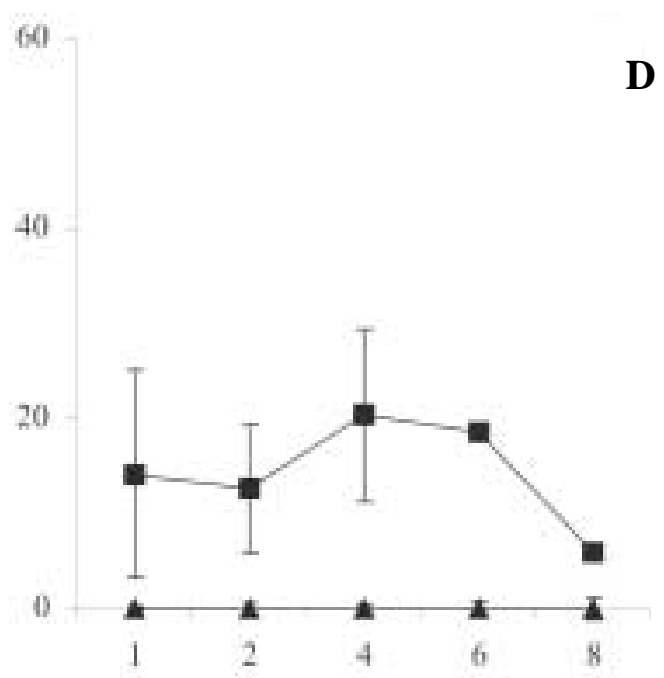

Tempo (h)

Figura 8. Conteúdo de ácidos urônicos (A, B) e atividade indutora de fitoalexinas em cotilédones de soja (C, D) dos hidrolisados

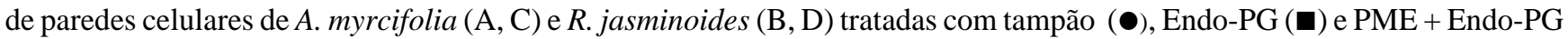
( $\mathbf{\Lambda})$ por diferentes períodos. As barras representam o desvio padrão da média.

Figure 8. Uronic acid content (A, B) and phytoalexin-inducing actitivy in soybean cotyledons (C, D) of cell wall hydrolysates of A. myrcifolia $(\mathrm{A}, \mathrm{C})$ and $R$. jasminoides $(\mathrm{B}, \mathrm{D})$ after treatment with buffer $(\bullet)$, Endo-PG $(\boldsymbol{\square})$ and \% PME + Endo-PG ( $(\boldsymbol{\bullet})$ for different periods. Bars represent average of triplicates \pm standard deviation.

tratamento com Endo-PG, sendo observados para $10 \mathrm{~min}$ oligogalacturonídeos em maior quantidade e com maior GP (figura 10B). Para essa espécie, o aumento do tempo de incubação com PME resultou na diminuição da proporção de oligogalacturonídeos de maior GP (figura 10D).

Na tabela 3 são apresentados os dados relativos aos ensaios de indução simultânea utilizando hidrolisados resultantes da incubação de paredes celulares de $R$. jasminoides tratados com Endo-PG e pré-tratados com PME. Observa-se que os hidrolisados de $R$. jasminoides com Endo-PG por $4 \mathrm{e}$ $6 \mathrm{~h}$ de incubação apresentaram atividade indutora de fitoalexinas, e que esta atividade foi pouco diminuída pela diluição a 50\% com água destilada. Porém, quando ao hidrolisado Endo-PG foi adicionado o hidrolisado resultante da incubação com PME + Endo-PG, essa atividade foi completamente abolida. Também o 

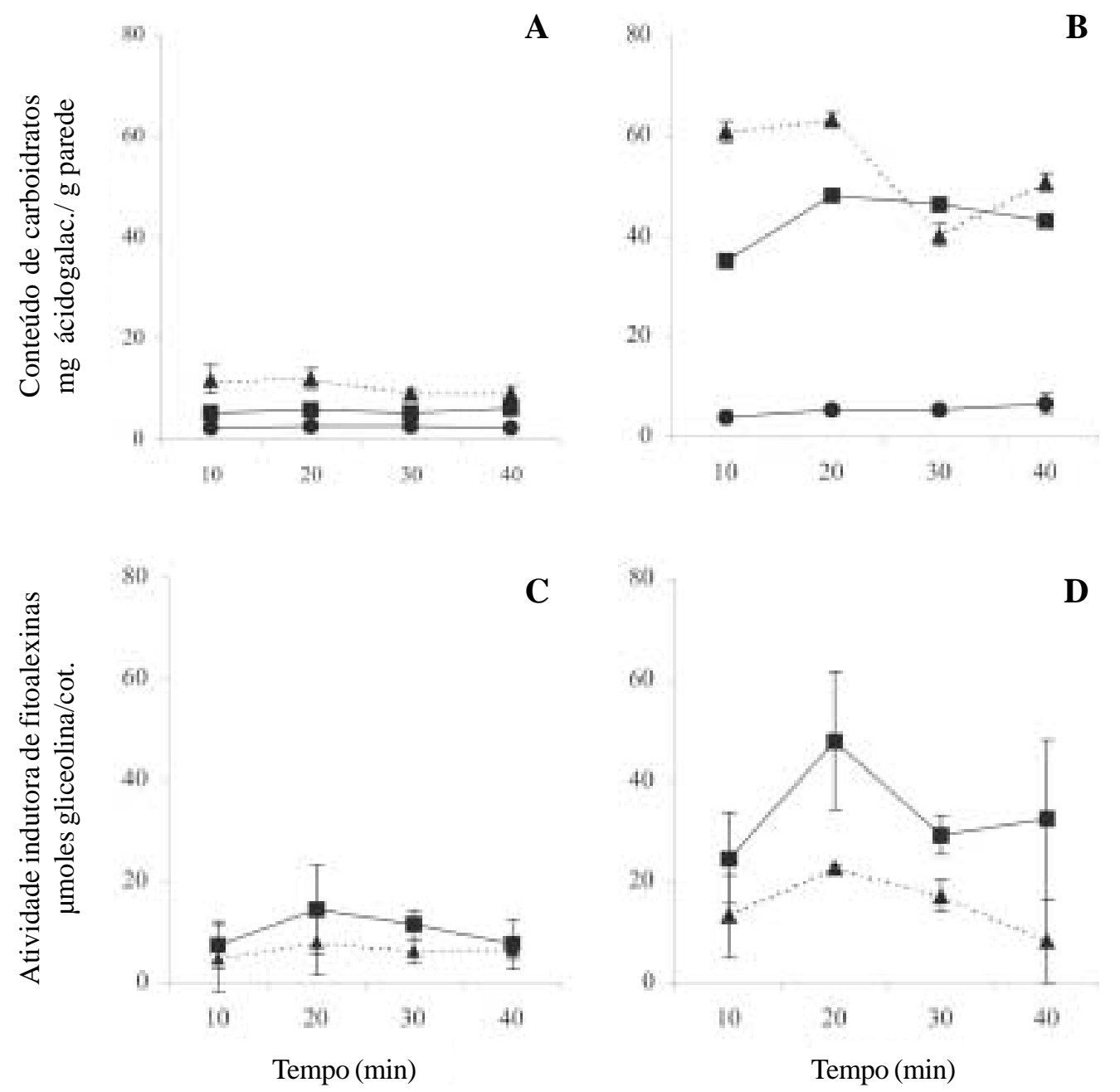

Figura 9. Conteúdo de ácidos urônicos (A, B) e atividade indutora de fitoalexinas em cotilédones de soja (C, D) dos incubados

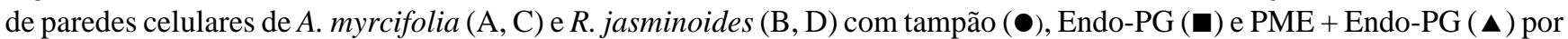
diferentes períodos com PME. As barras representam o desvio padrão da média.

Figure 9. Uronic acid content (A, B) and phytoalexin-inducing actitivy in soybean cotyledons (C, D) of cell wall hydrolysates of A. myrcifolia (A, C) and R. jasminoides (B, D) after treatment with buffer $(\bullet)$, Endo-PG (ם) and PME + Endo-PG ( $(\boldsymbol{\bullet})$ for different periods. Bars represent average of triplicates \pm standard deviation.

eliciador de $M$. ramosissimus, quando diluído no mesmo hidrolisado (PME + Endo-PG), apresentou queda significativa na atividade indutora, fato não observado na diluição com água. O hidrolisado com PME + Endo-PG de A. myrcifolia também ocasionou queda na atividade indutora do eliciador.

Outro ensaio de inibição, realizado somente com o eliciador de M. ramosissimus, é mostrado na figura 11. A aplicação do eliciador diluído em água destilada nas proporções entre $25 \%$ e $75 \%$ não alterou o padrão de sua atividade indutora de fitoalexinas. Entretanto, quando este foi aplicado nas mesmas proporções de diluição juntamente com os hidrolisados das paredes celulares de ambas espécies resultantes do tratamento combinado com PME seguida de Endo-PG, ocorreu inibição da atividade indutora.

\section{Discussão}

A incubação de paredes celulares de folhas de $A$. myrcifolia e $R$. jasminoides com Driselase revelou diferenças na labilidade das mesmas à hidrólise promovida por enzimas fúngicas e na liberação de fragmentos indutores da síntese de fitoalexinas em cotilédones de soja (figura 1). Estes resultados confirmam aqueles obtidos por Braga \& Dietrich (1998) e Braga et al. (1998), que indicaram a existência de diferenças na estrutura dos 

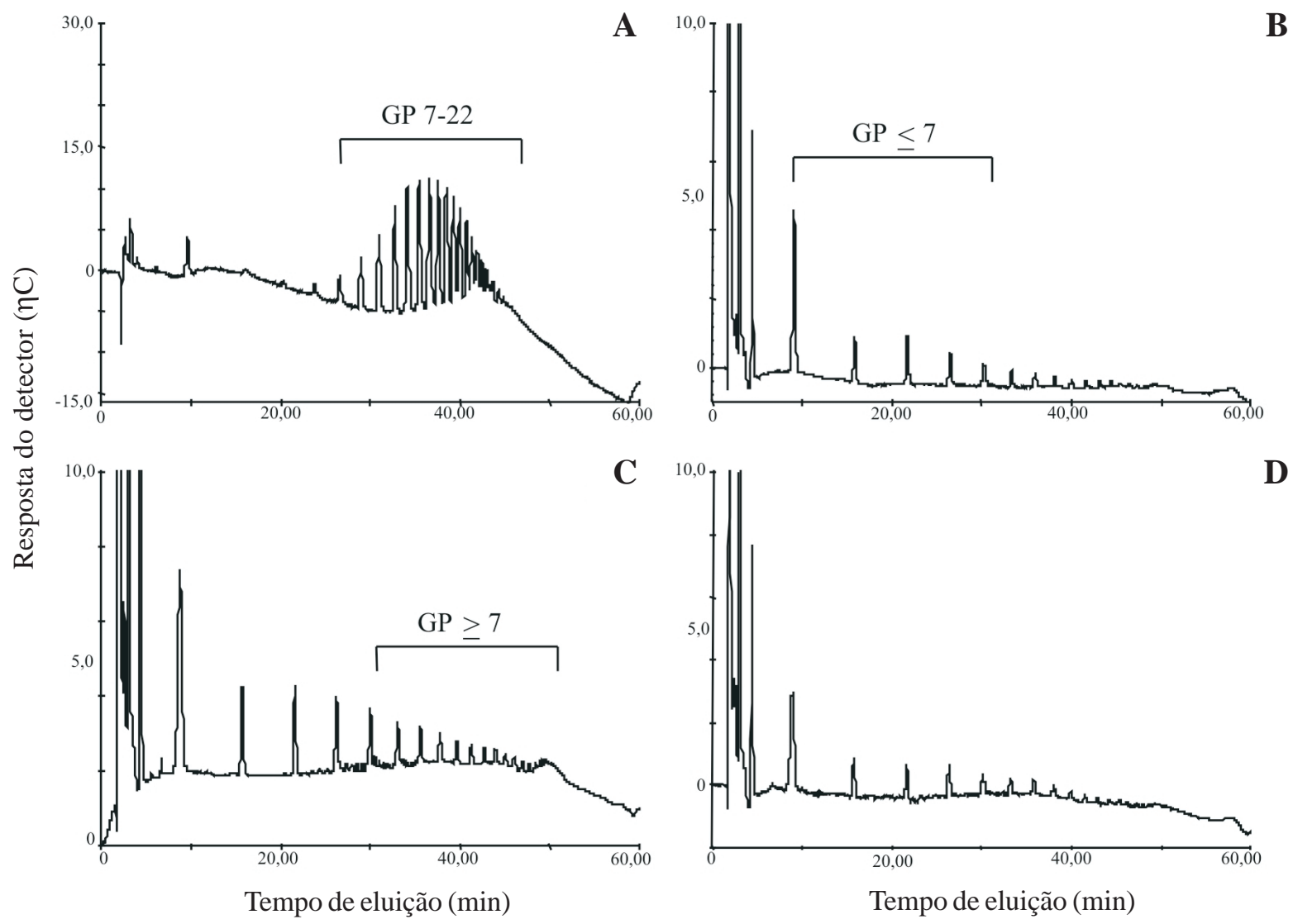

Figura 10. Perfil em HPAEC/PAD dos oligogalacturonídeos presentes nos hidrolisados de paredes celulares de $R$. jasminoides tratadas com Endo-PG 4h (B) e PME 10 min + Endo-PG 4h (C) e PME 40 min + Endo-PG 4 h (D). Padrão de oligolacturonídeos (A).

Figure 10. HPAEC/PAD profile of oligogalacturonides from cell walls of $R$. jasminoides incubated with Endo-PG $4 \mathrm{~h}(\mathrm{~B}), \mathrm{PME}$ $10 \mathrm{~min}+$ Endo-PG $4 \mathrm{~h}(\mathrm{C})$, and PME $40 \mathrm{~min}+$ Endo-PG $4 \mathrm{~h}$ (D). Standard of oligogalacturonides (A).

polissacarídeos das paredes celulares entre as espécies estudadas.

Braga \& Dietrich (1998) também observaram que paredes celulares de $R$. jasminoides incubadas por $18 \mathrm{~h}$ com Endo-PG eram mais facilmente hidrolisadas quando comparadas às de $A$. myrcifolia. Foi sugerido que essa diferença poderia estar relacionada à presença de resíduos de ácido galacturônico da pectina bastante substituídos por grupos metil-ésteres em A. myrcifolia, o que limitaria a ação da Endo-PG. A liberação diferencial de ramnose nos hidrolisados obtidos por tratamento com Driselase (tabela 1) é um indício da ação preferencial de Endo-PG sobre a fração péctica da parede celular de $R$. jasminoides, liberando RG-I e tornando-o suscetível a ação de outras hidrolases. Conforme citado por Ishii et al. (1989) e Zablackis et al. (1995), Endo-PGs têm sido utilizadas para o isolamento de RG-I a partir de paredes celulares de diversas espécies vegetais, por hidrolisarem homogalacturonanos pouco metilesterificados. Esses resultados, juntamente com aqueles obtidos nos ensaios colorimétricos para quantificação de grupos metil-ésteres e com o uso de anticorpos monoclonais específicos (figuras 3-6), os quais reconhecem diferentes graus de substituição de resíduos de ácido galacturônico por grupos metila, confirmaram a presença de pectinas pouco metilesterificadas em paredes celulares de folhas de $R$. jasminoides. Para A. myrcifolia, as quantificações por colorimetria e a imunolocalização não foram técnicas adequadas para se avaliar o grau de metilesterificação das pectinas, possivelmente pelo alto teor de compostos fenólicos presentes nas folhas, que interferiram com os ensaios (Braga et al. 1991).

Os resultados da tabela 2 indicam que paredes celulares de A. myrcifolia são pouco suscetíveis à hidrólise com Endo-PG quando comparadas à $R$. jasminoides, confirmando os dados de Braga \& Dietrich (1998). A hidrólise seqüencial com PME e Endo- 
Tabela 3. Atividade indutora de fitoalexinas de hidrolisados de paredes celulares de A. myrcifolia e $R$. jasminoides obtidos por tratamentos com PME por 40 min e 1 h e Endo-PG por 4 e 6 h, sobre cotilédones de soja. Os valores representam a média de 3 determinações. Médias seguidas de letras iguais em cada coluna não diferem estatisticamente a Tukey 5\%. - não ensaiado, * resultados de 3 ensaios conduzidos isoladamente, apresentados em colunas distintas, com os respectivos hidrolisados ensaiados.

Table 3. Phytoalexin-inducing activity on soybean cotyledons of cell wall hydrolysates of A. myrcifolia and R. jasminoides, after treatment with PME for $40 \mathrm{~min}$ and $1 \mathrm{~h}$, and Endo-PG for 4 and $6 \mathrm{~h}$. Values represent the average of triplicates. Letters compare averages in columns by Tukey $5 \%$. - not assayed, * results of three different assays, presented in different columns with their respective hydrolasates.

\begin{tabular}{|c|c|c|c|}
\hline \multirow[b]{2}{*}{ Amostra } & \multicolumn{3}{|c|}{$\mu$ moles gliceolina/cotilédone } \\
\hline & $\begin{array}{l}\text { R. jasminoides } \\
4 \mathrm{~h}\end{array}$ & $\begin{array}{l}\text { R. jasminoides } \\
6 \mathrm{~h}\end{array}$ & $\begin{array}{l}\text { A. myrcifolia } \\
4 \mathrm{~h}\end{array}$ \\
\hline Hidrolisado de parede com Endo-PG 100\% & $42,80 \mathrm{~d}$ & $70,0 \mathrm{~d}$ & - \\
\hline Hidrolisado de parede com PME+ Endo-PG 100\% & $36,66 \mathrm{e}$ & $43,5 \mathrm{a}$ & - \\
\hline $\begin{array}{l}\text { Hidrolisado de parede com Endo-PG diluído a 50\% } \\
\text { em } \mathrm{H}_{2} \mathrm{O} \text { destilada }\end{array}$ & $43,68 \mathrm{~d}$ & $50,6 \mathrm{e}$ & - \\
\hline $\begin{array}{l}\text { Hidrolisado de parede com Endo-PG diluído a 50\% } \\
\text { no hidrolisado PME+ Endo-PG }\end{array}$ & $33,73 \mathrm{e}$ & 35,5 a & - \\
\hline Eliciador de Mucor ramosissimus* & $177,64 \mathrm{a}$ & $113,9 \mathrm{~b}$ & 138,90 \\
\hline Eliciador de M. ramosissimus diluído a $50 \%$ em $\mathrm{H}_{2} \mathrm{O}$ destilada & $136,20 \mathrm{~b}$ & $118,4 b$ & - \\
\hline $\begin{array}{l}\text { Eliciador de M. ramosissimus diluído a 50\% } \\
\text { no hidrolisado PME + Endo-PG }\end{array}$ & $87,06 \mathrm{c}$ & $89,7 \mathrm{c}$ & 56,80 \\
\hline Controle (água destilada)* & $19,20 \mathrm{e}$ & $33,2 \mathrm{a}$ & 19,11 \\
\hline
\end{tabular}

PG aumentou em cerca de três vezes a quantidade de ácidos urônicos liberados, indicando que a eliminação de grupos metil-ésteres favoreceu a ação da Endo-PG sobre as paredes celulares de A. myrcifolia, o que comprova a elevada metilesterificação de sua pectina. Entretanto, a quantidade de ácidos urônicos liberada ainda foi bastante inferior à de $R$. jasminoides, sugerindo que não apenas o GM, mas outras características da parede celular de A. myrcifolia devem contribuir para esses resultados. Braga et al. (1998) demonstraram que a quantidade de ácidos urônicos encontrada nas pectinas de A. myrcifolia é cerca de 4,6 vezes menor do que a de $R$. jasminoides. Por essa razão, mesmo eliminando-se toda a metilesterificação dos homogalacturonanos da parede celular de A. myrcifolia através do tratamento prévio com PME, a quantidade de polissacarídeos ácidos disponíveis para a ação da Endo-PG ainda seria menor, o que poderia explicar a menor quantidade de ácidos urônicos liberada pela hidrólise das paredes celulares desta espécie.

Para $R$. jasminoides, cuja parede celular é facilmente hidrolisada pela Endo-PG, a incubação prévia com PME ou promoveu um pequeno aumento na hidrólise subsequiente com a Endo-PG (tabela 2),

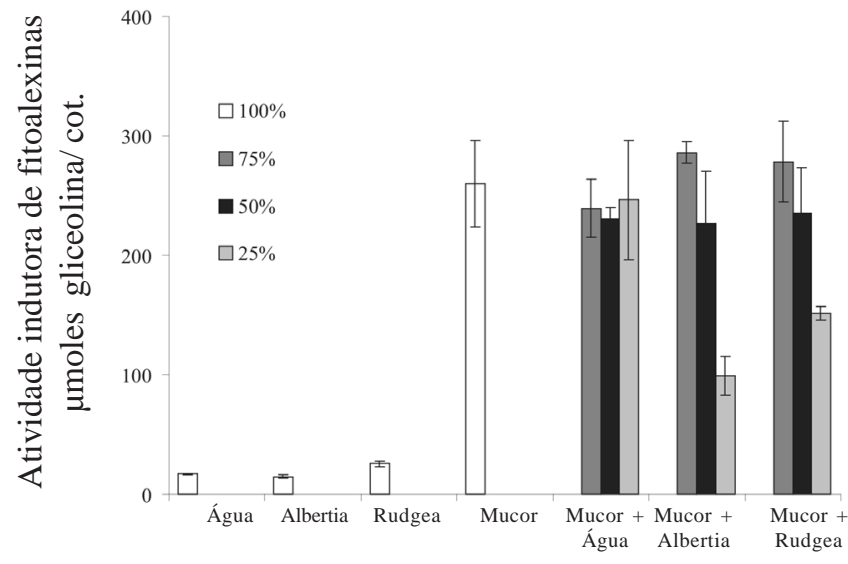

Figura 11. Atividade indutora de fitoalexinas em cotilédones de soja do eliciador de $M$. ramosissimus diluído a 25-75\% em água destilada, no hidrolisado PME $1 \mathrm{~h}+$ Endo-PG $4 \mathrm{~h}$ de $R$. jasminoides e no hidrolisado PME $40 \mathrm{~min}+$ Endo-PG $4 \mathrm{~h}$ de A. myrcifolia. As barras representam o desvio padrão da média.

Figure 11. Phytoalexin-inducing activity in soybean cotyledons of the eliciador of $M$. ramosissimus diluted to $25-75 \%$ in distilled water, in the PME $1 \mathrm{~h}+$ Endo-PG $4 \mathrm{~h}$ hydrolysate of $R$. jasminoides, and in the PME $40 \mathrm{~min}+$ Endo-PG $4 \mathrm{~h}$ hydrolysate of $A$. myrcifolia. Bars represent average of triplicates \pm standard deviation. 
ou resultou em redução da ação subseqüente da Endo-PG na clivagem da pectina (figura $8 \mathrm{~B}$ ), indicando que o GM de sua pectina é bastante inferior ao de A. myrcifolia. Mort \& Chen (1996) e Daas et al. (1999) relataram que as Endo-PGs fúngicas necessitam, usualmente, de uma estrutura composta por quatro resíduos de ácido galacturônico não esterificados numa região parcialmente esterificada para poder agir. No caso de $R$. jasminoides, o tratamento prévio com PME poderia alterar a estrutura molecular reconhecida pela Endo-PG, explicando assim a diminuição na porcentagem de hidrólise para esta espécie. É possível relacionar esse decréscimo no conteúdo de ácidos urônicos à provável eliminação excessiva de grupos metil-estéres. A diminuição do tempo de hidrólise com a PME (figura 9) indicou que até 30 minutos de incubação, a estrutura da pectina de $R$. jasminoides, alterada pela ação da PME, pareceu ser adequada ao reconhecimento e clivagem pela Endo-PG, com conseqüente liberação de fragmentos ativos. Após esse período, a incubação com PME parece retirar grupos metil-ésteres importantes para o reconhecimento pela Endo-PG, como sugerem os trabalhos realizados por Mort \& Chen (1996) e Daas et al. (1999). Entretanto, oligogalacturonídeos ativos (com GP $\geq 12$ ) ainda foram encontrados nesses hidrolisados, o que sugere a existência de um outro fator nos hidrolisados pré-tratados com PME que estaria determinando redução na atividade indutora de fitoalexinas quando comparados ao tratamento realizado unicamente com Endo-PG. Moerschbacher et al. (1999) relataram que, em folhas de trigo, oligômeros de ácido galacturônico de baixo GP atuam como supressores endógenos de reações de resistência. Dentre os oligogalacturonídeos ensaiados, os dímeros e trímeros se mostraram mais ativos, inclusive quando aplicados concomitantemente ao eliciador, um glicoproteogalactano, isolado do fungo Puccinia graminis, suprimindo sua atividade. Assim, é provável que os oligogalacturonídeos de pequeno GP gerados nos hidrolisados de A. myrcifolia e $R$. jasminoides estejam inibindo a atividade dos oligogalacturonídeos maiores, conforme sugerem os dados mostrados na tabela 3 e na figura 11. Esses resultados explicam a ausência de atividade indutora nos hidrolisados de $R$. jasminoides incubados com Driselase por 6-8 h (figura 1D), indicando que a perda de atividade pode ser atribuída não somente à quebra de fragmentos ativos já presentes no meio de incubação, mas também a um aumento de oligogalacturonídeos de pequeno GP, os quais poderiam estar suprimindo a indução.

Os resultados obtidos neste trabalho sugerem que a ação da PME sobre as pectinas das paredes celulares de ambas espécies pode regular a liberação de oligogalacturonídeos de diferentes GP. Assim, considerando-se que: a) a ação da PME sobre polissacarídeos pécticos influencia a especificidade posterior da Endo-PG; b) as pectinas apresentam diferentes GM e distribuição destes grupos metil-ésteres (Le Cam et al. 1994) e c) a Endo-PG atua diferentemente sobre cada substrato, dependendo da distribuição dos grupos metil-ésteres (Daas et al. 2000), resultando em diferenças na liberação de fragmentos maiores ou menores, é possível supor que a distribuição dos grupos metil-ésteres na pectina seja de extrema importância no processo de liberação de oligogalacturonídeos ativos, requeridos no processo de indução de fitoalexinas. Além disso, a proporção relativa entre os fragmentos de diferentes GP, gerados durante a maceração dos tecidos, pode contribuir para a resposta final de defesa. Assim, sugere-se que a relação entre os fragmentos menores e maiores possa estar envolvida na regulação fina do processo de eliciação, ainda não bem compreendida. De acordo com essa sugestão, fragmentos ativos liberados durante o processo de infecção ocasionariam a ativação do sistema de defesa da planta; com o decorrer do processo, fragmentos menores, inativos, gerados pela degradação excessiva das pectinas ou dos fragmentos maiores, poderiam suprimir a indução por se apresentarem em maior proporção, consequentemente desligando o sistema de defesa da planta.

Le Cam et al. (1994) observaram que o grau de suscetibilidade de cultivares de cenoura ao ataque do fungo Mycocentrospora acerina está relacionado ao GM das pectinas que compõem as paredes celulares. No presente trabalho, a utilização de enzimas hidrolíticas de parede celular demonstrou a existência de diferenças na labilidade de paredes de rubiáceas ao ataque destas enzimas. A ausência de hidrólise de paredes celulares de A. myrcifolia com Endo-PG parece estar relacionada ao alto GM de sua fração péctica. O uso de Driselase demonstrou que fragmentos ativos são liberados a partir da parede de $A$. myrcifolia, porém com a necessidade de um tempo de incubação maior do que aquele requerido para paredes de $R$. jasminoides. Isto provavelmente decorre da necessidade de que outras hidrolases presentes na Driselase (além da PME e da Endo-PG) atuem previamente sobre a parede de A. myrcifolia, de maneira a permitir a ação posterior da Endo-PG sobre a mesma. Para R. jasminoides, moléculas ativas são 
liberadas de sua parede celular, porém a distribuição dos grupos metil-ésteres anterior e posteriormente à ação da PME também são fatores limitantes para a ação da Endo-PG e, conseqüentemente, para a liberação de oligogalacturonídeos ativos. Possivelmente, oligogalacturonídeos de pequeno GP atuam como supressores endógenos da reação de defesa da planta, conforme previamente relatado por Boudart et al. (1995) para a síntese de proteínas ricas em hidroxiprolina. Todos estes fatores interferem com a capacidade de resposta destas espécies quando em contato com microorganismos e podem estar relacionados ao comportamento diferencial observado entre A. myrcifolia e R. jasminoides com relação à sua capacidade de produzir fitoalexinas quando inoculadas com fungos.

Agradecimentos - As autoras agradecem a Glenn Freshour da Universidade da Georgia - EUA pelo auxílio técnico na obtenção de cortes para Microscopia Eletrônica de transmissão, à Fundação de Amparo a Pesquisa do Estado de São Paulo (Fapesp) pela bolsa concedida para a primeira autora (processo $n^{\circ}$ 99/01218-0) e ao CNPq pela bolsa de produtividade em pesquisa a M.R. Braga.

\section{Referências bibliográficas}

ALGHISI, P. \& FAVARON, F. 1995. Pectin degrading enzymes and plant-parasite interactions. European Journal of Plant Pathology 101:365-375.

AYERS, A., EBEL, J., FINELLI, F., BERGER, N. \& ALBERSHEIM, P. 1976. Host-Pathogen Interactions IX. Quantitative assays of elicitor activity and characterization of the elicitor present in the extracellular medium of cultures of Phytophthora megasperma var. sojae. Plant Physiology 57:751-759.

BOUDART, G., DECHAMP-GUILLAUME, G., LAFITTE, C., RICART, G., BARTHE, J.P., MAZAU, D. \& ESQUERRÉTUGAYÉ, M.T. 1995. Elicitors and supressors of hydroxyproline-rich glycoprotein accumulation are solubilized from plant cell walls by endopoligalacturonase. European Journal of Biochemistry 232:449-557.

BRAGA, M.R. \& DIETRICH, S.M.C. 1998. Phytoalexininducing oligosaccharins from the cell walls of tropical Rubiaceae. Revista Brasileira de Fisiologia Vegetal 10:79-84.

BRAGA, M.R., YOUNG, M.C.M., DIETRICH, S.M.C. \& GOTTLIEB, O.R. 1991. Phytoalexin induction in Rubiaceae. Journal of Chemical Ecology 17:1079-1090.

BRAGA, M.R., BOM PESSONI, R.A. \& DIETRICH, S.M.C. 1998. Cell wall polysaccharide composition of leaves of tropical Rubiaceae differing in phytoalexin response. Revista Brasileira de Fisiologia Vegetal 10:71-78.
CERVONE, F., DE LORENZO, G., DEGRÁ, L., SALVI, G. \& BERGAMI, M. 1987. Purification and characterization of a polygalacturonase-inhibiting protein from Phaseolus vulgaris L. Plant Physiology 85:631-637.

CERVONE, F., DELORENZO, G., SALVI, G., BERGMANNC., HAHN, M.G., ITO, Y., DARVILL, A. \& ALBERSHEIM, P. 1989. Release of phytoalexin elicitor-activity oligogalacturonides by microbial pectic enzymes. In Signal molecules in plants and plant-microbe interactions. (B.J.J. Lutgtenberg, ed.). NATO ASI Series, Springer-Verlag, Heidelberg, v. H36, p.85-89.

CORDEIRO NETO, F. \& DIETRICH, S.M.C. 1992. Phytoalexin induction by leaf-surface fungi of tropical Rubiaceae. Ciência e Cultura 44:342-344.

CÔTË, F. \& HAHN, M.G. 1994. Oligosaccharins: structures and signal transduction. Plant Molecular Biology 26:1379-1411.

DAAS, J.H.P., MEYER-HANSEN, K., SCHOLS, H.A., DE RUITER, G.A. \& VORAGEN, A.G.J. 1999. Investigation of the non-esterified galacturonic acid distribution in pectin with endopolygalacturonase. Carbohydrate Research 318:135-145.

DAAS, J.H.P., VORAGEN, A.G.J. \& SCHOLS, H. 2000. Characterization of non-esterified galacturonic acid sequences in pectin with endopolygalacturonase. Carbohydrate Research 326:120-129.

DARVILL, A.G., AUGUR, C., BERGMANN, C., CARLSON, R.W., CHEONG, J.J., EBEHARD, S., HAHN, M.G., LÓ, V.M., MARFÁ, V., MEYER, B., MOHNEN, D., O'NEILL, M.A., SPIRO, M.D., VAN HALBEEK, H., YORK, W.S. \& ALBERSHEIM, P. 1992. Oligosaccharins oligosaccharides that regulate growth, development, and defense responses in plants. Glycobiology 2:181-198.

DAVIS, K.R., LYON, G.D., DARVILL, A.G. \& ALBERSHEIM, P. 1984. Host-Pathogen Interactions. XXV. Endopolygalacturonic acid lyase from Erwinia carotovora elicits phytoalexin accumulation by releasing plant cell fragments. Plant Physiology 68:221-228.

DUBOIS, M., GILLES, A., HAMILTON, J.K., REBERS, P.A. \& SMITH, F. 1956. Colorimetric method for determination of sugars and related substances. Analytical Chemistry 28:350-355.

FILISETTI-COZZI, T.M.C.C. \& CARPITA, N.C. 1991. Measurement of uronic acids without interference from neutral sugars. Analytical Biochemistry 197:157-162.

FRAISSINET-TACHET, L. \& FEVRE, M. 1996. Regulation by galacturonic acid of pectinolytic enzyme production by Sclerotinia sclerotiorum. Current Microbiology 33:49-53.

FRESHOUR, G., CLAY, R.P., FULLER, M.S., ALBERSHEIM, P., DARVILL, A.G. \& HAHN, M.G. 1996. Developmental and tissue-specific structural alterations of the cell wall polysaccharides of Arabidopsis thaliana roots. Plant Physiology 110:1413-1429. 
FRY, S.C. 1988. The Growing Plant Cell Wall: chemical and metabolic analysis. Longman, New York.

HAHN, M.G., DARVILL, A. \& ALBERHSEIM, P. 1981. HostPathogen Interactions. XIX. The endogenous elicitor, a fragment of a plant cell wall polysaccharide that elicit phytoalexin accumulation in soybeans. Plant Physiology 68:1161-1169.

HEITEFUSS, R. \& PAGEL, W. 1989. Calcium content and cell wall polygalacturonans in potato tubers of cultivars with different susceptibilities to Erwinia carotovora subsp. atroseptica. Physiological and Molecular Plant Pathology 35:11-21.

ISHII, T., THOMAS, J., DARVILL, A. \& ALBERSHEIM, P. 1989. Structure of plant cell walls XXVI. The walls of suspension-cultured sycamore cells contain a family of ramnogalacturonan-I-like pectic polysaccharides. Plant Physiology 89:421-428.

KNOX, J.P., LINSTEAD, P.J., KING, J., COOPER, C. \& ROBERTS, K. 1990. Pectin esterification is spatially regulated both within cell walls and between developing tissues of root apices. Planta 181:512-521.

LE CAM, B., MASSIOT, P., CAMPION, C. \& ROUXEL, F. 1994. Susceptibility of carrot cultivars to Mycocentrospora acerina and the structure of cell wall polysaccharides. Physiological and Molecular Plant Pathology 45:139-151.

MCCANN, M.C., SHI, J., ROBERTS, K. \& CARPITA, N.C. 1994. Changes in pectin structure and localization during the growth of unadapted and $\mathrm{NaCl}$-adapted tobacco cells. The Plant Journal 5:773-785.

MCMILLAN, G.P., HEDLEY, D., FYFFE, L. \& PÉROMBELON, M.C.M. 1993. Potato resistance to soft-rot erwinias is related to cell wall pectin esterification. Physiological and Molecular Plant Pathology 42:279-289.

MCNEIL, M., DARVILL, A. \& ALBERSHEIM, P. 1984. Structure and function of primary cell walls of plants. Annual Review of Biochemistry 53:625-663.

MOERSCHBACHER, B.M., MIERAU, M., GRAEBNER, B., NOLL, U. \& MORT, A.J. 1999. Small oligomers of galacturonic acid are endogenous supressors of disease resistance reactions in wheat leaves. Journal of Experimental Botany 50:605-612.
MORT, A.J. \& CHEN, E.M.W. 1996. Nature of sites hydrolyzable by endopolygalacturonase in partiallyesterified homogalacturonans. Carbohydrate Polymers 29:129-136.

NOTHNAGEL, E.A., MCNEIL, M. \& DELL, A. 1983. HostPathogen Interactions. XXII. A galacturonic acid oligosaccharide from plant cell wall elicits phytoalexins. Plant Physiology 71:916-926.

SAKAI, T., SAKAMOTO, T., HALLAERT, J. \& VANDAMME, E.J. 1993. Pectin, pectinase and protopectinase: production, properties and aplications. Advances and Applications in Microbiology 39:213-294.

SOMOGYI, M. 1945. A new reagent for the determination of sugars. Journal of Biological Chemistry 160:61-68.

SPIRO, M.D., KATES, K.A., KOLLER, A.L., O’NEILL, M.A., ALBERSHEIM, P. \& DARVILL, A.G. 1993. Purification and characterization of biologically active 1,4-linked ". D-oligogalacturonides after partial digestion of polygalacturonic acid with endopolygalacturonase. Carbohydrate Research 247:9-20.

VIDAL, B.C. 1977. Acid glucosaminoglycans and endochondral ossification. Cellular and Molecular Biology 22:45-64

WILLATS, W.G.T., LIMBERG, G., BUCHHOLT, H.C., VAN ALEBEEK, G-J., BENEN, J., CHRISTENSEN, T.M.I.E., VISSER, J., VORAGEN, A., MIKKELSEN, J.D. \& KNOX, J.P. 2000. Analysis of pectic epitopes recognised by hybridoma and phage display monoclonal antibodies using defined oligosaccharides, polysaccharides, and enzymatic degradation. Carbohydrate Research 327:309-320.

WILLATS, W.G.T., MCCARTNEY, L., MACKIE, W. \& KNOX, P. 2001. Pectin: cell biology and prospects for functional analysis. Plant Molecular Biology 47:9-27.

WOOD, P.J. \& SIDDIQUI, I.R. 1971. Determination of methanol and its application to measurement of pectin methyl ester content and pectin methylesterase activity. Analytical Biochemistry 39:418-428.

ZABLACKIS, E., HUANG, J., MULLER, B., DARVILL, A.G. \& ALBERSHEIM, P. 1995. Characterization of the cell-wall polysaccharides of Arabidopsis thaliana leaves. Plant Physiology 107:1129-1138. 